\title{
Predictive Value of Urinary Neutrophil Gelatinase- associated Lipocalin and Serum Ischemia-modified Albumin for Early Diagnosis in Patients with Contrast- induced Acute Kidney Injury
}

\author{
Idrar Nötrofil Jelatinaz lilşkili Lipokalin ve Serum iskemi Modifiye Albümin \\ Düzeylerinin Kontrastla illişkili Böbrek Hasarının Erken Tanısında Öngördürücü Değeri \\ ๑ Ziya Apaydın, ๑ Alparslan Kılıç*, ๑ Berkay Ekici**, ๑ Aycan Fahri Erkan**, \\ - Sedat Özdemir***, ๑ Ali Kemal Oğuz ${ }^{* \star *}$ \\ University of Health Sciences Turkey, Haseki Training and Research Hospital, Clinic of Cardiology, Istanbul, Turkey \\ ${ }^{*}$ Koç University Faculty of Medicine Hospital, Clinic of Cardiology, Istanbul, Turkey \\ ** Ufuk University Faculty of Medicine, Department of Cardiology, Ankara, Turkey \\ ***Ufuk University Faculty of Medicine, Department of Biochemistry, Ankara, Turkey \\ $* * * *$ Ufuk University Faculty of Medicine, Department of Internal Diseases, Ankara, Turkey
}

Abstract

Aim: The aim of this study was to investigate whether urinary neutrophil gelatinase-associated lipocalin (NGAL) and serum ischemia-modified albumin (IMA) levels could serve as early biomarkers of contrast-induced acute kidney injury (Cl-AKI) in patients with normal serum creatinine values who undergo coronary angiography (CAG).

Methods: This study was conducted in 78 patients undergoing CAG. Urinary NGAL and serum IMA values which measured prior to and 6 hours after CAG were compared with creatinine values that measured prior to and 48 hours after CAG.

Results: IMA and NGAL values obtained 6 hours after CAG differed significantly from those obtained at baseline. Statistically significant differences were found between the baseline and 6th-hour values of urinary NGAL and serum IMA $(p<0.001)$. There was no significant difference between baseline and $48^{\text {th }}$ hour serum creatinine levels ( $p=0.081$ ). In addition, a statistically significant positive correlation was found between pre-processing

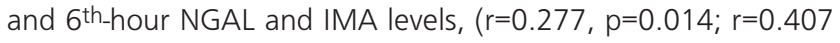
and $p<0.001$, respectively).

Conclusion: An increase in urinary NGAL and serum IMA levels were detected without an increase in serum creatinine values which is routinely used in determining CI-AKI. When compared
Amaç: Serum iskemi modifiye albümin (IMA) ve idrar nötrofil jelatinaz ilişkili lipokalin (NGAL) gibi biyobelirteçler kontrastla ilişkili böbrek hasarının erken tanısında umut vadetmektedirler. $\mathrm{Bu}$ çalışmanın amacı serum kreatinin düzeyleri normal olup koroner anjiyografi yapılan hastalarda idrar NGAL ve serum IMA düzeylerinin kontrastla ilişkili böbrek hasarının erken teşhisinde kullanılabilecekleri hipotezini araştırmaktır.

Yöntemler: Çalışmaya elektif koroner anjiyografi (KAG) uygulanan 78 hasta alındı. KAG'den önce ve 6 saat sonra ölçülen idrar NGAL ve serum IMA değerleri, KAG'den önce ve 48 saat sonra ölçülen kreatinin değerleri ile karşılaştırıldı.

Bulgular: Idrar NGAL ve serum IMA değerlerinin başlangıç ve 6. saat değerleri arasında istatistiksel olarak anlamlı fark izlendi $(p<0,001)$. Başlangıç ve 48. saat serum kreatinin değerleri arasında anlamlı fark izlenmedi $(p=0,081)$. Ek olarak, işlem öncesi ve 6. saat NGAL ve IMA düzeyleri arasında pozitif korelasyon izlendi (sırasıyla $r=0,277, p=0,014 ; r=0,407$ ve $\mathrm{p}<0,001)$.

Sonuç: Çalışmamızda, kontrastla ilişkili böbrek hasarının teşhisinde kullanılan serum kreatinin değerlerinde bir artış olmadan üriner NGAL ve serum IMA düzeylerinde anlamlı artış izlendi. Serum kreatinin ile karşılaştırıldığında, idrar NGAL ve
Address for Correspondence/Yazışma Adresi: Alparslan Kılıç, Koç University Faculty of Medicine Hospital, Clinic of Cardiology, İstanbul, Turkey E-mail: dr-alp@hotmail.com ORCID: orcid.org/0000-0002-2308-197X

Received/Geliş Tarihi: 31 December 2019 Accepted/Kabul Tarihi: 21 February 2020
${ }^{0}$ Copyright 2020 by The Medical Bulletin of istanbul Haseki Training and Research Hospital The Medical Bulletin of Haseki published by Galenos Yayınevi.

Telif Hakkı 2020 istanbul Haseki Eğitim ve Araştırma Hastanesi Haseki Tıp Bülteni, Galenos Yayınevi tarafından yayınlanmıştır. 


\section{Abstract}

to serum creatinine, urinary NGAL and serum IMA may be early and sensitive biomarkers for predicting CI-AKI.

Keywords: Neutrophil gelatinase-associated lipocalin, ischemia modified albumin, contrast-induced acute kidney injury
Öz

serum IMA, kontrastla ilişkili böbrek hasarını tahmin etmek için erken ve hassas bir biyobelirteç olarak kullanılabilir.

Anahtar Sözcükler: Nötrofil jelatinaz ilişkili lipokalin, iskemi modifiye albümin, kontrastla ilişkili böbrek hasarı

\section{Introduction}

Contrast-induced acute kidney injury (Cl-AKI) is one of the more common serious complications of cardiac catheterization and coronary angiography (CAG) (1). ClAKI occurs in $10-20 \%$ of patients after contrast media exposure in CAG (2). A lot of studies have shown that $\mathrm{Cl}-\mathrm{AKI}$ is linked to many worst outcomes and prolonged hospitalization (3). CI-AKI is the third leading cause of hospital-acquired renal failure $(11.3 \%)$ (4). For this reason, after contrast media exposure, serum creatinine $(\mathrm{s} C r)$ and other renal function tests should be monitored with serial measurements in all patients who have risk factors for $\mathrm{Cl}-\mathrm{AKI}$ (1). Cl-AKI has been defined as an increase in sCr levels more than $25 \%$ within three days after intravascular contrast administration (4). $\mathrm{SCr}$, known as the classical biomarker of renal function, has low sensitivity and it is affected by many variables such as race, gender, age, total body volume, changes in muscle mass and tubular secretion (5). SCr is not a useful marker for early diagnosis of CI-AKI since increases in SCr levels are usually observed 48-72 hours after contrast medium administration. Therefore, we need new kidney biomarkers for early detections of $\mathrm{Cl}$ $\mathrm{AKI}$ and to estimate prognosis in patients with kidney injury.

Recent studies have shown that novel and more sensitive biomarkers such as neutrophil gelatinaseassociated lipocalin (NGAL) can be used for early diagnosis of Cl-AKI (4-6). NGAL, known as kidney troponin, is a 25$\mathrm{kDa}$ protein covalently bound to gelatinase from human neutrophils (5). It might be one of the earliest potential markers of renal tubular injury.

Ischemia-modified albumin (IMA) is a variation of albumin which is the most abundant plasma protein in human plasma. The task of the albumin is to transport divalent ions such as cobalt with the N-terminal end of albumin. Depending on the ischemia and reactive oxygen molecules formed secondary to ischemia, changes occur at the $\mathrm{N}$-terminal end of albumin. As a result, the ability of albumin to bind cobalt is disrupted. IMA has been associated with acute ischemia before necrosis. IMA could be used as an early biomarker for CI-AKI (7).
In this study, we investigated the use of urinary NGAL and serum IMA in early diagnosis of $\mathrm{CI}-\mathrm{AKI}$ in patients undergoing CAG and receiving contrast media.

\section{Methods}

\section{Study Population}

This research was planned as a prospective observational cohort study and we included 93 consecutive individuals. Characteristic features of the patient group (78 patients) were as follows: 1) patients with stable angina pectoris, 2) patients with ischemic electrocardiogram changes, positive treadmill test, or positive myocardial perfusion scintigraphy (MPS), 3) patients who received contrast media for CAG eGFR value $>60 \mathrm{~mL} / \mathrm{min} / 1.73 \mathrm{~m}^{2}$ calculated using the modification of diet in renal disease-MDRD equation). In order to compare the baseline values of the patient group, 15 individuals with demographic and clinical characteristics compatible with the patient group who did not undergo CAG and did not receive contrast media were included in the study (control group). Thus, we ensured that there were no independent factors affecting the baseline measurements and that the contrast agent volume was the only factor that would affect the markers of renal function and cause nephrotoxicity 6 hours after contrast agent administration.

The study was approved by Ufuk University Faculty of Medicine, Dr. Ridvan Ege Hospital Noninvasive Evaluation Committee (decision no: 311020131, date: 31.10.2013) and all patients gave written informed consent. Cardiomyopathy, permanent pacemaker, presence of severe atrioventricular conduction defect, left ventricular hypertrophy, left ventricular systolic dysfunction (ejection fraction $<40 \%$ ), moderate to severe valvular heart disease, hypertensive heart disease, acute pericarditis, myocarditis, congenital heart disease, acute coronary syndrome, skeletal muscle disease, G3-5 stage renal function impairment (according to the MDRD formula eGFR value < $60 \mathrm{~mL} / \mathrm{min} / 1.73 \mathrm{~m}^{2}$ ), severe electrolyte imbalance, history of contrast media exposure within one week, and known nephrotoxic drug exposure comprised the exclusion criteria. 
All patients were given $1 \mathrm{cc} / \mathrm{kg} /$ hour isotonic $\mathrm{NaCl} 4$ hours before the procedure and intravenous isotonic $\mathrm{NaCl}$ infusion was continued for 12 hours after the procedure. Diuretics and metformin were routinely withheld $24 \mathrm{~h}$ before the procedure.

\section{Laboratory Values}

Urinary NGAL and serum IMA were measured before and 6 hours after the procedure. $\mathrm{SCr}$ and blood urea nitrogen (BUN) levels were measured before and 48 hours after the procedure and all measurements were compared. Thyroid-stimulating hormone (TSH), pro-brain natriuretic peptide (pro-BNP), and urinary NGAL levels were assessed by chemiluminescent microparticle immunoassay tests using an Abbott Architect i2000 (Abbott INC., USA) device. Serum-urine creatinine, BUN, low-density lipoprotein (LDL), high-density lipoprotein (HDL) and triglyceride levels were assessed by the calorimetric method using an Abbott Architect C8000 (Abbott INC., USA) device. Complete blood count was studied usng the ABBOTT CELL DYN 3700 (Abbott INC, USA) with 22-parameter impedancelaser technology. HbA1c was measured by Agilent 1100 series (Agilent Technologies, Germany) with the highperformance liquid chromatography method. Serum IMA level was assessed spectrophotometrically by the Humalayz 2000 (HUMAN INC, Germany).

\section{Definitions}

$\mathrm{Cl}-\mathrm{AKI}$ has been defined as an increase of more than $25 \%$ in $\mathrm{sCr}$ levels within three days of intravascular contrast administration (4). Hypertension was defined as a blood pressure (BP) of $>140 / 90 \mathrm{mmHg}$ or 24-h ambulatory BP $>130 / 80 \mathrm{mmHg}$ according to the European Society of Cardiology guidelines. Hyperlipidemia was defined as a total cholesterol level of $>240 \mathrm{mg} / \mathrm{dL}$ or lipid-lowering drug use. Current smoking was defined as smoking one or more cigarettes per day for at least 1 year. Type 2 Diabetes Mellitus was defined according to the American Diabetes Association guidelines as previous diagnosis and/ or a fasting blood glucose level of $>126 \mathrm{mg} / \mathrm{dL}$ or use of antidiabetic medications. Body Mass index (BMI) was calculated according to the following formula: weight $(\mathrm{kg}) /$ height $(\mathrm{m})^{2}$. eGFR was calculated using the MDRD equation $\left[\left((186.3 \times \mathrm{sCr}-1.154) \times\left(\mathrm{age}^{-0.203}\right) \times(0.742\right.\right.$ if female)] (8).

\section{Statistical Analysis}

The data were analyzed using the PASW Statistics version 18 program. Descriptive statistics were shown as mean \pm standard deviation for continuous variables, and nominal variables were shown as number and percentage (\%). The normality assumption of the data was evaluated with the Kolmogorov-Smirnov test. A chi-square test was used to compare the nominal data. Correlation between continuous data was analyzed by Spearman correlation coefficient. The significance of the statistical difference between independent groups (control group vs patient group) was investigated by the Mann-Whitney U test. Two or more related groups were evaluated by the Wilcoxon matched-pairs signed rank test. A $p$ value of $<0.05$ was considered statistically significant.

\section{Results}

There was no statistically significant difference in renal function and nephrotoxicity markers $(\mathrm{s} C r, \mathrm{BUN}$, urine creatinine, NGAL, IMA) before the CAG procedure between the two groups. Thus, we found that there were no independent factors that would affect the baseline measurements and the only factor that would affect the change in renal function and nephrotoxicity markers was the contrast agent to be given in the measurements performed 6 hours after contrast agent administration. Table 1 shows the main characteristics of the patient and control groups. As shown in Table 1, no statistically significant difference was found between control and patient groups in terms of age, gender, BMI, hypertension, hyperlipidemia, smoking history and eGFR. Laboratory data of the patient and control groups are compared in Table 2. As shown in Table 2, there was no statistically significant difference in haemoglobin ( $\mathrm{Hgb})$, platelets, LDL, HDL, triglycerides, TSH, HgbA1C, pro-Brain natriuretic

\begin{tabular}{|c|c|c|c|}
\hline Characteristics & Patient group $(n=78)$ & Control group ( $n=15$ ) & p \\
\hline Age (years) & $61.79 \pm 11.58$ & $62.46 \pm 15.78$ & 0.758 \\
\hline Gender, (male/female), $n$ & $52 / 26$ & $9 / 6$ & 0.768 \\
\hline $\mathrm{BMI}, \mathrm{kg} / \mathrm{m}^{2}$ & $28.61 \pm 3.74$ & $28.40 \pm 4.33$ & 0.963 \\
\hline $\mathrm{HT},(\%)$ & 74.4 & 66.7 & 0.537 \\
\hline $\mathrm{HL},(\%)$ & 60.3 & 46.7 & 0.397 \\
\hline DM, (\%) & 28.2 & 40.0 & 0.371 \\
\hline Current smoking, (\%) & 34.6 & 34.1 & 0.587 \\
\hline GFR $($ mean \pm SD) & $88.35 \pm 14.74$ & $91.33 \pm 15.17$ & 0.392 \\
\hline
\end{tabular}


peptide (0. hour), BUN (0. hour) $\mathrm{s} C r$ (0. hour), urine creatinine (0. hour), NGAL (0. hour), and IMA (0. hour) between the groups. As shown in Table 3, we found that Oh IMA and 6h IMA were significantly different in the patient's group. Similarly, 0-6 h NGAL and 0-48 h BUN was significantly different in the patient's group. There was no significant difference between baseline and $48^{\text {th }}$ hour $\mathrm{sCr}$ level in the patient group. In addition, $0^{\text {th }} \mathrm{h}$ and $6^{\text {th }}$ hour urinary NGAL/urinary creatinine ratio was significantly different in the patient's group. We found a significant positive correlation between baseline IMA-NGAL values and $6^{\text {th }}$ hour IMA-NGAL $(r=0.277, p=0.014$ and $r=0.407$, $p<0.001$, respectively)

\section{Discussion}

$\mathrm{Cl}-\mathrm{AKI}$ is a frequent complication that can be observed after some radiologic and angiographic examinations. Several studies have shown that CI-AKI was associated with higher morbidity and mortality rates and longer hospital stay (9). Therefore, early detection of CI-AKI might reduce morbidity and mortality rate and length of hospital stay. Early detection of $\mathrm{Cl}-\mathrm{AKI}$ can prevent clinical adverse events. In addition, early diagnosis is challenging since the patients for whom the decision of medical treatment was taken were discharged on the same day or 24 hours later. In our study, there was no statistically significant difference between baseline and $48^{\text {th }}$ hour $\mathrm{SCr}$ levels in patient group. Maybe the results would have been different if the creatine levels could be checked at 72 hours. However, glomerular function impairment began before the increase in SCR levels. However, SCR, which is the traditional marker of $\mathrm{CI}-\mathrm{AKI}$, is not a reliable biomarker for early detection of $\mathrm{Cl}-\mathrm{AKI}$, because it generally increases 48-72 hours after contrast media exposure. When the increase in SCR levels is detected, a significant loss in kidney function might have been started (10). The aim of this study was to investigate the diagnostic value of urine NGAL and serum IMA levels for early detection of CI-AKI. To the best of our knowledge, there is no research about the use of urine NGAL and serum IMA for early detection of Cl-AKI.

IMA, known as a marker of ischemia, increases in many clinical conditions such as acute coronary syndrome, endstage renal disease, liver failure, cerebrovascular diseases,

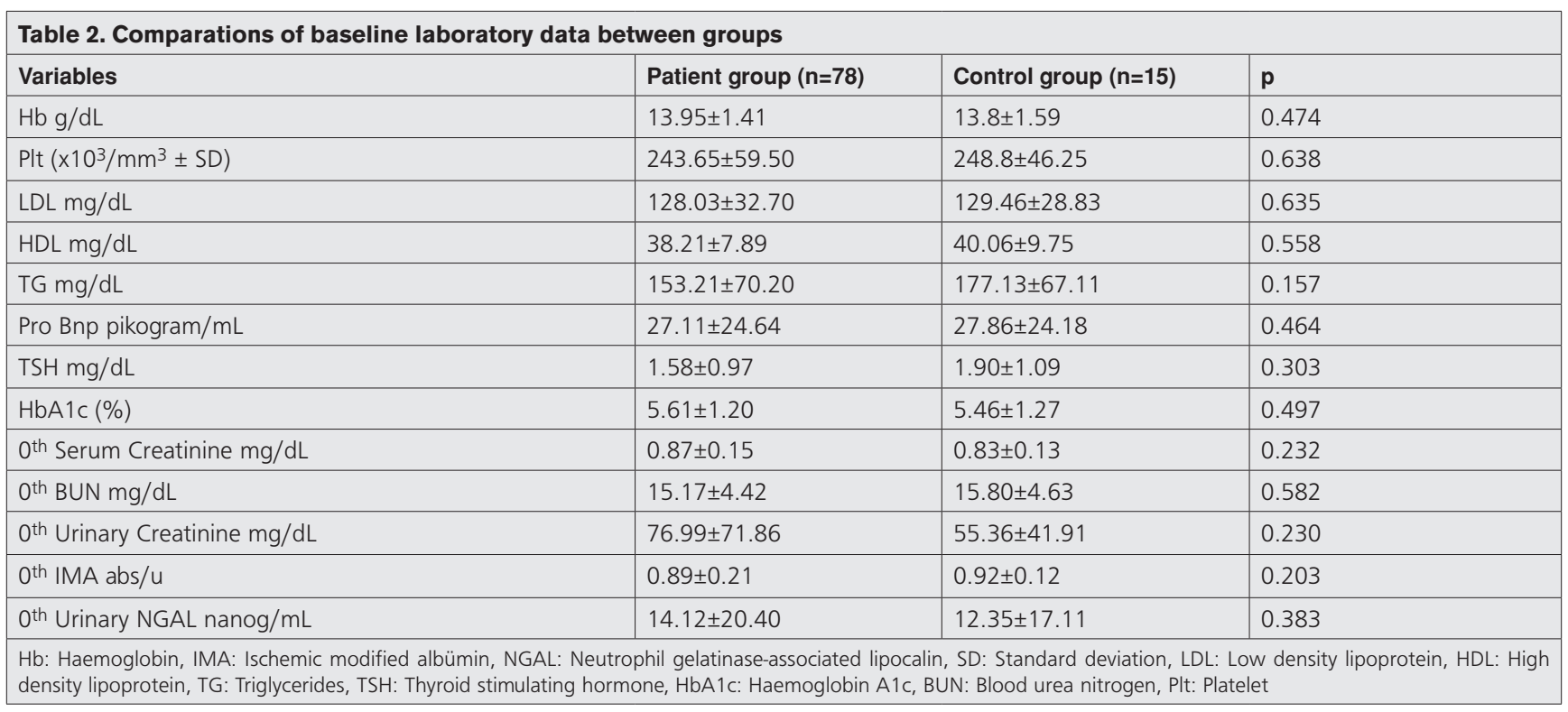

\begin{tabular}{|l|l|l|l|l|}
\hline \multicolumn{7}{|l|}{ Table 3. Changes in serum creatinine, BUN, Urinary creatinine, NGAL and IMA after iodine contrast exposure } \\
\hline Variables & Baseline & $\mathbf{6}^{\text {th }}$ after procedure & $\mathbf{4 8}^{\text {th }}$ after procedure & $\mathbf{p}$ \\
\hline Creatinine & $0.87 \pm 0.15$ & $\mathrm{Nm}$ & $0.96 \pm 0.35$ & 0.081 \\
\hline BUN & $15.17 \pm 4.42$ & $\mathrm{Nm}$ & $18.67 \pm 8.52$ & $<0.001$ \\
\hline Urinary creatinine & $76.99 \pm 71.86$ & $49.19 \pm 32.08$ & $140.84 \pm 78.52$ & $\begin{array}{l}\mathrm{B}-6 \mathrm{~h}<0.001 \\
\mathrm{~B}-48 \mathrm{~h}<0.001\end{array}$ \\
\hline Serum IMA & & & $\mathrm{Nm}$ & $<0.001$ \\
\hline Urinary NGAL & $0.89 \pm 0.21$ & $1.05 \pm 0.29$ & $\mathrm{Nm}$ & $<0.001$ \\
\hline Urinary NGAL/Urinary Creatinine & $14.12 \pm 20.40$ & $32.48 \pm 52.95$ & $\mathrm{Nm}$ & $<0.001$ \\
\hline Nm: Not measured, IMA: Ischemic modified albümin, NGAL: Neutrophil gelatinase-associated lipocali, BUN: Blood urea nitrogen & \\
\hline
\end{tabular}


severe trauma, some neoplastic diseases, pulmonary embolism, deep vein thrombosis and infections, and superior mesenteric artery occlusion (11). A two-phase vascular response is observed after contrast media administration, firstly short-term vasodilatation, secondly long-term vasoconstriction in the renal artery. This situation is the main pathophysiologic mechanism of $\mathrm{Cl}$ AKI (12). Increased vascular resistance reduces intrarenal blood flow and GFR (13). Compared to the renal cortex, the renal medulla, which has lower perfusion and partial oxygen pressure, is much more affected by the decrease in intrarenal blood flow (14). As a result of opening the shunt with contrast agent effect, intrarenal blood flow direction changes from the medulla to the cortex (14). Ultimately, hypoxia occurs in the medulla. According to our hypothesis, IMA levels which are used as a predictor of ischemic organ damage might be increased in CI-AKI. To the best of our knowledge, there are no studies about the relationship between serum IMA levels and $\mathrm{CI}-\mathrm{AKI}$ in the literature. We found that $6^{\text {th }}$ hour serum IMA level was increased compared to the baseline level in this study.

NGAL is released from many tissues in the organism such as the gastrointestinal tract, bronchus, and renal tubule. It stimulates the transformation of renal progenitor cells toward renal tubular epithelial cells. Increased serum NGAL level may support regeneration and repair of the renal tubule when renal tubular damage has occurred. A lot of studies have demonstrated that serum NGAL, known as renal troponin, is a sensitive biomarker for early detection of Cl-AKI (15-17). Hirsch et al. (18) determined a cut-off value of $100 \mathrm{ng} / \mathrm{mL}$ for NGAL for the detection of CI-AKI in paediatric patients with a sensitivity of $73 \%$ and a specificity of $100 \%$. In their meta-analysis including 19 studies involving 2,538 patients, Haase et al. (19) have shown that measurement of $6^{\text {th }}$ hour serum NGAL level had a high sensitivity for early detection of $\mathrm{Cl}$ AKI. In addition, a lot of studies have shown that urine NGAL had a higher predictive value compared to serum NGAL $(16,20)$. Bachorzewska-Gajewska et al. (21) have compared NGAL and Cystatin C levels for the risk of developing $\mathrm{Cl}-\mathrm{AKI}$ in 26 adult patients who underwent CAG. Although CI-AKI did not develop, they found that 4th$8^{\text {th }}$ hour urine NGAL levels and $2^{\text {th }} 4^{\text {th }}$ hour serum NGAL levels significantly increased compared to baseline levels. Bachorzewska et al. (22) reported a significant increase in serum NGAL after 2 and 4 hours and in urinary NGAL 4 and 8 hours after CAG and they observed that these values returned to baseline levels within 48 hours. Similar to the literature, we found increased levels of urine NGAL 6 hours after CAG compared to the baseline level. In this study, we investigated IMA, an important ischemia marker that was not previously investigated in the early diagnosis of Cl-AKI, and urinary NGAL, which is an important marker for showing renal damage. Serum IMA and urinary NGAL were compared with $\mathrm{SCr}$ which is the standard approach in the diagnosis of $\mathrm{Cl}-\mathrm{AKI}$.

\section{Study Limitations}

This study has several limitations: Its small sample size was a significant limitation. Second, since prophylactic treatments and precautions that are used to prevent the development of $\mathrm{Cl}-\mathrm{AKI}$ are routinely applied in our clinic, we predicted small number of $\mathrm{CI}-\mathrm{AKI}$ cases. In the literature, the incidence of $\mathrm{Cl}-\mathrm{AKI}$ development was reported to be between $4 \%$ and $50 \%$. The reason for the absence of $\mathrm{Cl}$ AKI may be prophylactic treatment routinely applied before the procedure. Although routine prophylactic treatments performed in our clinic during CAG are effective, it made it difficult to evaluate the changes that we wanted to examine in our study.

\section{Conclusion}

In the light of these data, we can say that urine NGAL and serum IMA might be used as early markers for CI-AKI in patients without an increase in the SCR level.

\section{Authorship Contributions}

Concept: A.K.O., A. F.E., B.E. Design: A.K.O., A.F.E., B.E. Data Collection or Processing: A.K., Z.A. Analysis or Interpretation: B.E., S.Ö. Literature Search: A.K., Z.A. Writing: A.K., Z.A.

Conflict of Interest: No conflict of interest was declared by the authors.

Financial Disclosure: The authors declared that this study received no financial support.

\section{References}

1. Solomon R, Deray G. How to prevent contrast-induced nephropathy and manage risk patients: practical recommendations. Kidney International 2006;69:S51-S3.

2. Nguyen LS, Spagnoli $V$, Kerneis $M$, et al. Evaluation of neutrophil gelatinase-associated lipocalin and cystatin C as biomarkers of acute kidney injury after ST-segment elevation myocardial infarction treated by percutaneous coronary intervention. Archives of cardiovascular diseases 2019;112:180-6.

3. McCullough PA. Contrast-induced acute kidney injury. Journal of the American College of Cardiology 2008;51:1419-28.

4. Akgul E, Kilıç A, Korkmaz FŞ, et al. Is cystatin-c superior to creatinine in the early diagnosis of contrast-induced nephropathy a potential new biomarker for an old complication. 2014;60:135-40.

5. Cecchi E, Avveduto G, D'Alfonso MG, et al. Cystatin C, but not urinary or serum NGAL, may be associated with contrast 
induced nephropathy after percutaneous coronary invasive procedures: A single center experience on a limited number of patients. Acta medica academica 2017;46.

6. Nusca A, Miglionico M, Proscia C, et al. Early prediction of contrast-induced acute kidney injury by a "bedside" assessment of Neutrophil Gelatinase-Associated Lipocalin during elective percutaneous coronary interventions. Plos one 2018;13:e0197833.

7. Kocan H, Citgez S, Yucetas U, et al. Can ischemia-modified albumin be used as an objective biomarker for renal ischemic damage? An experimental study with wistar albino rats. Transplantation proceedings. Elsevier 2014;46:3326-9.

8. Levey AS, Coresh J, Bolton $\mathrm{K}$, et al. K/DOQI clinical practice guidelines for chronic kidney disease: evaluation, classification, and stratification. American Journal of Kidney Diseases 2002;39.

9. Levy EM, Viscoli CM, Horwitz RI. The effect of acute renal failure on mortality: a cohort analysis. Jama 1996;275:148994.

10. Mishra J, Ma Q, Prada A, et al. Identification of neutrophil gelatinase-associated lipocalin as a novel early urinary biomarker for ischemic renal injury. Journal of the American Society of Nephrology 2003;14:2534-43.

11. Bar-Or D, Lau E, Winkler JV. A novel assay for cobaltalbumin binding and its potential as a marker for myocardial ischemia-a preliminary report. The Journal of emergency medicine 2000;19:311-5.

12. Seeliger E, Flemming B, Wronski T, et al. Viscosity of contrast media perturbs renal hemodynamics. Journal of the American Society of Nephrology 2007;18:2912-20.

13. Finkel KW, Murray PT, Shaw A. Prevention of acute renal failure in the intensive care unit. Intensive Care in Nephrology: CRC Press; 2005. p. 122-62.

14. Detrenis S, Meschi M, Musini S, et al. Lights and shadows on the pathogenesis of contrast-induced nephropathy: state of the art. Nephrology Dialysis Transplantation 2005;20:154250 .

15. Devarajan P. Neutrophil gelatinase-associated lipocalin: A troponin-like biomarker for human acute kidney injury. Nephrology 2010;15:419-28.

16. Ling $\mathrm{W}$, Zhaohui $\mathrm{N}$, Ben $\mathrm{H}$, et al. Urinary IL-18 and NGAL as early predictive biomarkers in contrast-induced nephropathy after coronary angiography. Nephron Clinical Practice 2008;108:c176-c81.

17. Shaker O, El-Shehaby A, El-Khatib M. Early diagnostic markers for contrast nephropathy in patients undergoing coronary angiography. Angiology 2010;61:731-6.

18. Hirsch R, Dent C, Pfriem $H$, et al. NGAL is an early predictive biomarker of contrast-induced nephropathy in children. Pediatric Nephrology 2007;22:2089.

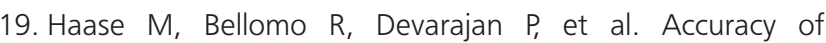
neutrophil gelatinase-associated lipocalin (NGAL) in diagnosis and prognosis in acute kidney injury: a systematic review and meta-analysis. American Journal of Kidney Diseases 2009;54:1012-24.

20. Bagshaw SM, Bennett M, Haase $M$, et al. Plasma and urine neutrophil gelatinase-associated lipocalin in septic versus non-septic acute kidney injury in critical illness. Intensive care medicine 2010;36:452-61.

21. Bachorzewska-Gajewska H, Malyszko J, Sitniewska E, et al. Neutrophil gelatinase-associated lipocalin (NGAL) correlations with cystatin $C$, serum creatinine and eGFR in patients with normal serum creatinine undergoing coronary angiography. Nephrology Dialysis Transplantation 2006;22:295-6.

22. Bachorzewska-Gajewska H, Malyszko J, Sitniewska E, et al. Could neutrophil-gelatinase-associated lipocalin and cystatin C predict the development of contrast-induced nephropathy after percutaneous coronary interventions in patients with stable angina and normal serum creatinine values? Kidney and Blood Pressure Research 2007;30:408-15. 